\title{
Green recycling of chicken feather and sheep wool using the partially purified alkaline protease from Bacillus circulans $\mathrm{L}$.
}

\author{
Eman Fathi Sharaf*, Khadijah Al-Fadel \\ Department of Biology, Faculty of Science, Taibah University, Al-Madinah Al-Munawarah, KSA; \\ *Corresponding Author: emanfsharaf@yahoo.com
}

Received 23 April 2013; revised 28 May 2013; accepted 6 June 2013

Copyright (C) 2013 Eman Fathi Sharaf, Khadijah Al-Fadel. This is an open access article distributed under the Creative Commons Attribution License, which permits unrestricted use, distribution, and reproduction in any medium, provided the original work is properly cited.

\begin{abstract}
The previously optimized crude alkaline protease from the haloalkaliphilic Bacillus circulans $L$. was partially purified using ammonium sulphate fractionation and dialysis. The best specific activity $(27.7 \mathrm{U} / \mathrm{mg}$ protein) was obtained at $80 \%$ saturation. The optimum reaction temperature and reaction $\mathrm{pH}$ was $47^{\circ} \mathrm{C}$ and 9 , respectively. The enzyme activity was enhanced with $\mathrm{Ca}$ and $\mathrm{K}$ chlorides but suppressed with $\mathrm{HgCl}_{2}$ and EDTA. The partially purified protease showed strong proteolytic activity on sheep wool and chicken feather. Also, the enzyme was compatible with the common detergent Tide and could improve its cleaning power in removing blood stain. These findings support the application of the present alkaline protease in biotechnological industries.
\end{abstract}

Keywords: Bacillus; Alkaline Protease; Ammonium Sulphate Precipitation; Characterization; Feather; Wool; Blood Stains

\section{INTRODUCTION}

Proteases are hydrolytic enzymes that degrade protein into polypeptides, dipeptides and then to amino acids [1]. In particular, bacterial alkaline proteases play an important role in the industrial biotechnological processes and they are one of the highest value commercial enzymes as they have broad applications in food, pharmaceutical, detergent, and dairy industries [2]. Of them, Bacillus species are considered the most efficient for such purpose as they produce large quantities of the enzyme [3-5].

Purification and biochemical characterization of enzymes, used in industry, are urgent to optimize their activity. Enzymes can be partially purified by precipitation with ammonium sulphate which was used to precipitate protease from Bacillus subtilis [6], B. cereus [7,8] and another Bacillus sp. [9].

In addition to their wide applications, alkaline proteases have received an increasing importance in degradation of different waste materials like sheep wool, dehairing and leather processing [10] and degradation of feathers resulted from chicken processing [11]. Such degradation can minimize the environmental pollution resulting from disposal of these wastes. Moreover, alkaline proteases could be exploited in detergent industry, as well [12, 13].

Accordingly, the present work aimed at partial purification and characterization of the previously optimized alkaline protease from the haloalkaliphilic Bacillus circulans L. and its possible use in hydrolysis of sheep wool, chicken feathers as well as its compatibility with a common detergent.

\section{MATERIALS AND METHODS}

\subsection{Organism}

The haloalkaliphilic Bacillus circulans L., previously isolated from hypersaline alkaline soil at Al-Madinah Al-Munawarah, KSA, was optimized for alkaline protease production [14]. The optimized medium contained (g\%): sucrose, 0.5; $\mathrm{NH}_{4} \mathrm{NO}_{3}, 0.1 ; \mathrm{K}_{2} \mathrm{HPO}_{4}, 0.1 ; \mathrm{MgSO}_{4}$. $7 \mathrm{H}_{2} \mathrm{O}, 0.02$ and $\mathrm{NaCl}, 10$. The medium $\mathrm{pH}$ was adjusted to 8.5 (optimum $\mathrm{pH}$ ). The inoculated flasks (optimum inoculums age was $48 \mathrm{~h}$ ) were incubated under shaking at $45^{\circ} \mathrm{C}$ for $48 \mathrm{~h}$ (optimum temperature and optimum incubation period) and the culture filtrate was collected.

\subsection{Partial Purification of Protease}

The culture filtrate of Bacillus circulans 1 was centrifuged at $3000 \mathrm{rpm}$ for $15 \mathrm{~min}$ under cooling and the cell 
free filtrate (CFF) was collected. A known volume of the CFF was subjected to elevated concentrations of ammonium sulphate (20\% - 100\% saturation) to precipitate the protein [15]. At each precipitation step, the obtained precipitate was dissolved in $5 \mathrm{ml}$ of $0.5 \mathrm{M}$ borax- $\mathrm{NaOH}$ buffer ( $\mathrm{pH}$ 8.5). The enzyme activity was assayed using casein solution $(0.6 \%$ casein in $0.5 \mathrm{M}$ Boric acid- $\mathrm{NaOH}$ buffer, $\mathrm{pH}$ 9.0) as substrate $[14,16]$ and the protein content was estimated [17]. The specific activity was then calculated. The precipitated enzyme preparation obtained from the most suitable level of ammonium sulphate (80\%) was dialyzed overnight against sucrose and specific activity was calculated. After dialysis the enzymereaction mixture was investigated for optimum temperature and $\mathrm{pH}$ and the effect of some metal ions.

\subsection{Protease Characterization}

The optimum reaction temperature was determined by incubating the enzyme with substrate (casein) for $30 \mathrm{~min}$ at different temperatures $27^{\circ} \mathrm{C}, 37^{\circ} \mathrm{C}, 47^{\circ} \mathrm{C}, 57^{\circ} \mathrm{C}$ and $67^{\circ} \mathrm{C}$ then protease activity was assayed. The optimum $\mathrm{pH}$ for enzyme activity was investigated by adjusting the reaction mixture at different $\mathrm{pHs}$ ranging from $6-10$ using borax- $\mathrm{NaOH}$ buffer. Incubation was conducted at $47^{\circ} \mathrm{C}$ (the best reaction temperature) for $30 \mathrm{~min}$ then protease activity was measured. The effect of chloride salt of some metal ions, as well as EDTA (5 mM) on protease activity was also investigated.

\subsection{Proteolytic Activity of the Partially Purified Enzyme on Wool and Feather}

Sheep wool and chicken feathers were used as a substrate instead of casein. They were dried, ground well and mixed separately (600 mg) with $100 \mathrm{ml}$ boric acid$\mathrm{NaOH}$ buffer at the optimum $\mathrm{pH}$ (9). One $\mathrm{ml}$ of this mixture was added to $1 \mathrm{ml}$ of enzyme and incubated at $47^{\circ} \mathrm{C}$ for $30 \mathrm{~min}$. Then $2 \mathrm{ml}$ of TCA solution was added to stop the enzyme reaction and the proteolytic activity was estimated in the filtrate as previously mentioned [14, $16]$.

\subsection{Compatibility of the Enzyme with the Common Detergent Tide}

Application of the partially purified protease as a detergent additive was studied on white cotton cloth pieces $(4 \times 4 \mathrm{~cm})$ stained with blood. Four blood stained cloth pieces were placed separately in flasks containing $100 \mathrm{ml}$ dist. water. One piece is left without any treatment for comparison (control) and the other three ones were treated separately with either: $1 \mathrm{ml}$ Tide detergent $(7 \mathrm{mg} / \mathrm{ml})$, $1 \mathrm{ml}$ enzyme solution or $1 \mathrm{ml}$ Tide detergent $(7 \mathrm{mg} / \mathrm{ml})+$ $1 \mathrm{ml}$ of enzyme solution. The flasks were incubated at $60^{\circ} \mathrm{C}$ for 15 minutes. Stain removal was observed visu- ally.

\subsection{Statistical Analysis}

The data presented were means of 3 replicates. The standard error was calculated by Microsoft Excel software. Analysis of variance to determine the significant differences $(\mathrm{P}<0.01)$ between means using SPSS statistical software was applied.

\section{RESULTS AND DISCUSSION}

\subsection{Partial Purification of Protease}

In the present study, optimized alkaline protease from B. circulans 1 was partially purified through precipitation with ammonium sulphate which almost had a minimum harmful effect on protein [15]. Ammonium sulfate is costless and efficiently soluble salt, so it is often used for such processes [18].

Ammonium sulfate fractionation pattern of protease revealed that the highest enzyme activity $(933.3 \mathrm{U} / \mathrm{ml})$ as well as the total protein $(33.7 \mathrm{mg} / \mathrm{ml})$ was obtained by $80 \%$ saturation with specific activity $27.7 \mathrm{U} / \mathrm{mg}$ protein (Table 1). After dialysis protease activity increased to 935.2 U/ml with 1.02-fold increase (data not shown).

It was observed that the crude enzyme had a higher activity as compared to the partially purified one which suggested the presence of certain compounds in the crude enzyme playing a role in enzyme stability and activity [9].

\subsection{Protease Characterization}

The present partially purified alkaline protease was investigated for the optimum reaction temperature, where the highest enzyme activity was obtained at $45^{\circ} \mathrm{C}, 47^{\circ} \mathrm{C}$ and $57^{\circ} \mathrm{C}$ with an optimum at $47^{\circ} \mathrm{C}$ at which an increase of about 1.01 -fold of activity at $45^{\circ} \mathrm{C}$ (the initial reaction temperature) was achieved (Figure 1). In this regard, the optimum reaction temperature was $55^{\circ} \mathrm{C}$ for protease activity of Bacillus sp. JSGT and above it the enzyme

Table 1. Ammonium sulphate fractionation pattern of Bacillus circulans L. protease.

\begin{tabular}{cccc}
\hline $\begin{array}{c}\text { Ammonium sulphate } \\
\text { saturation }(\%)\end{array}$ & $\begin{array}{c}\text { Protein content } \\
(\mathrm{mg} / \mathrm{ml})\end{array}$ & $\begin{array}{c}\text { Protease activity } \\
(\mathrm{U} / \mathrm{ml})\end{array}$ & $\begin{array}{c}\text { Specific } \\
\text { activity }\end{array}$ \\
\hline Crude extract & $73.0 \pm 3.1$ & $1032.0 \pm 7.9$ & 14.1 \\
20 & $14.3 \pm 0.6$ & $59.6 \pm 2.1$ & 4.2 \\
40 & $18.3 \pm 0.5$ & $124.4 \pm 2.6$ & 6.8 \\
60 & $25.7 \pm 1.9$ & $435.5 \pm 4.3$ & 16.9 \\
80 & $33.7 \pm 1.3$ & $933.3 \pm 5.9$ & 27.7 \\
100 & $11.0 \pm 0.8$ & $80.0 \pm 2.6$ & 7.3 \\
\hline
\end{tabular}




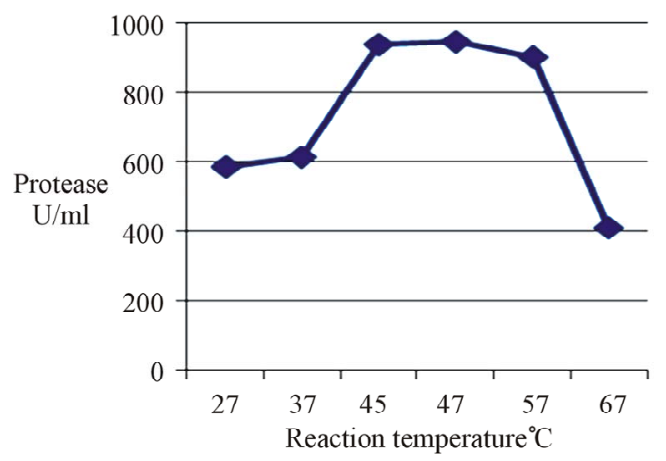

(a)

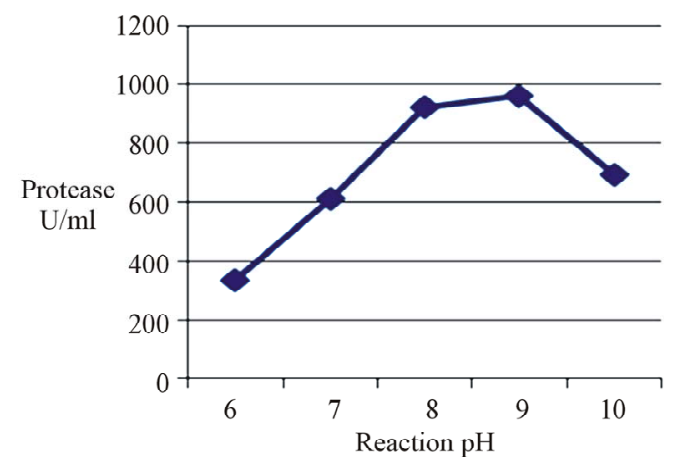

(b)

Figure 1. Effect of reaction temperature and reaction $\mathrm{pH}$ on the enzyme activity. (a) L.S.D.@1\%: 6.8; (b) L.S.D.@1\%: 9.3.

denatured and lost its activity [19] while that of B. cohnii APT5 [20] and B. cereus protease [8] was $50^{\circ} \mathrm{C}$. However, the optimum reaction temperature for a strain of Brevibacillus sp. was $70^{\circ} \mathrm{C}$ [21].

Reaction $\mathrm{pH}$ plays an important role in the activity of enzymes. The present protease exhibited great activity in the $\mathrm{pH}$ range of 6 - 10 (Figure 1) with an optimum at $\mathrm{pH}$ 9 (963 U/ml). Similar result was documented [19,22,23]. However, pH 8 and 10 was optimum for protease activity of Brevibacillus sp. [21] and B. cereus [8], respectively.

Interestingly, it was clearly observed that at $\mathrm{pH} 10$ the enzyme activity $(695 \mathrm{U} / \mathrm{ml})$ was reduced but it was still more than that recorded at $\mathrm{pH} 7(612 \mathrm{U} / \mathrm{ml}, 1.14$-fold increase). These results confirm the alkaliphilic nature of the present enzyme.

It is worthy to mention that, most industrial proteases are produced by Bacillus spp. and are neutral or alkaline. Bacillus spp. are favored in biotechnological industries due to their low generation time, which leads to short growth period, and due to their ability to produce extracellular proteins into the medium [5,24] .

The results of the effect of metal salts and metal chelator EDTA on enzyme activity revealed that EDTA had negatively affected the activity where only $35 \%$ of the control has been retained (Table 2). The inhibition exerted by EDTA, which is a chelating agent for calcium
Table 2. Effect of some metal ions and EDTA on the enzyme activity.

\begin{tabular}{ccc}
\hline Metal salt (mM) & Protease (U/ml) & Residual activity (\%) \\
\hline Control & 935.2 & 100 \\
$\mathrm{CuCl}_{2}$ & 833.0 & 89 \\
$\mathrm{MnCl}_{2}$ & 914.0 & 97 \\
$\mathrm{KCl}$ & 966.3 & 104 \\
$\mathrm{CaCl}_{2}$ & 984.5 & 106 \\
$\mathrm{ZnCl}_{2}$ & 573.6 & 61 \\
$\mathrm{HgCl}_{2}$ & 40.0 & 4 \\
EDTA & 328 & 35 \\
L.S.D.@1\% & 4.3 & \\
\hline
\end{tabular}

ions, may indicate that the present enzyme belonged to metallo-proteases. The inhibition of EDTA to alkaline protease activity of Brevi bacillus sp. [21], halophilic Halogeometrium boringuenes [25] and Bacillus cohniiAPT5 [20] was reported. Oppositely, the thermostable alkaline protease from Lactobacillus brevis was strongly activated by EDTA [23].

The activity of the present enzyme was stimulated when treated with $\mathrm{CaCl}_{2}$ or $\mathrm{KCl}$ where 106 and 104\% increase of the control was achieved, respectively (Table 2). Stimulation of either $\mathrm{Ca}$ or $\mathrm{K}$ ions was reported for protease of Lactobacillus brevis [23] and another Bacillus sp. [26], respectively. In this regard, calcium ions play a role in stabilization and activation of the halophilic Halogeometrium boringuenes protease [25]. This fact is clear in the present investigation as EDTA (chelating agent for calcium ions) caused a great suppression (65\%). In addition, some metal ions can protect enzymes from the harmful effect of temperature and play a role in conserving the active site of the enzymes at higher salt concentrations and higher pHs [27]. Moreover, it is urged to know the convenient metal ions and metal concentration for activation and stabilization of the enzymes which are used in commercial levels [28].

Table 2 also revealed that, while $\mathrm{MnCl}_{2}$ exhibited slight suppression on enzyme activity (residual activity 97\%), $\mathrm{CuCl}_{2}$ and $\mathrm{ZnCl}_{2}$ were more suppressive (residual activity 89 and 61\%, respectively). Similar result was observed for alkaline protease from Brevibacillus sp. strain PLI-1 where $\mathrm{Cu}^{2+}$ and $\mathrm{Zn}^{2+}$ could almost completely inhibit the activity of the enzyme [21]. On the contrary, alkaline protease activity of Bacillus cohnii APT5 increased by 53\% when treated with $\mathrm{Mn}^{2+}$ [20].

On the other hand, the highest suppression on activity was detected by $\mathrm{HgCl}_{2}$ where only $4 \%$ of this activity was retained. Similarly, $\mathrm{Hg}^{2+}$ strongly inhibited alkaline protease activity of Bacillus sp. [26] and Lactobacillus 
brevis [23]. The inhibition exerted by some metal ions as $\mathrm{Hg}^{2+}$ might be due to their interference with the enzyme functional group like SH group [26].

\subsection{Proteolytic Activity of the Enzyme on Wool and Feather}

The present enzyme exhibited high proteolytic activity towards both wool and feather substrates, with the former being more digested (Table 3). These findings suggested the application of the present alkaline protease in the dehairing and leather processing [10]. Protease from Kocuria rosea showed high affinity towards feathers than other substrates [11].

\subsection{Compatibility of Protease with the Common Detergent Tide}

It is worthy to mention that, the present alkaline protease from Bacillus circulans L. was not only stable in presence of Tide detergent but also has a great efficiency in cleaning blood stains from piece of cloth either alone or in mixture with the detergent (Figure 2) but with the latter being more effective and giving the best cleaning

Table 3. Proteolytic activity of B. circulans L. Protease on wool and feather.

\begin{tabular}{cc}
\hline Protienaceous substrate & Proteolytic activity $(\mathrm{U} / \mathrm{ml})$ \\
\hline Sheep wool & $231.4 \pm 0.6$ \\
Chicken feather & $170.6 \pm 2.6$ \\
\hline
\end{tabular}

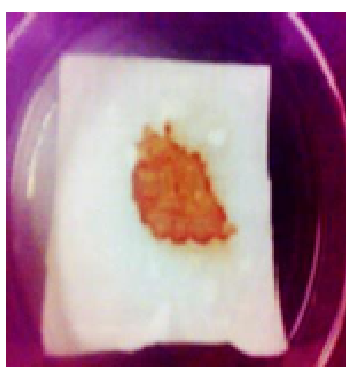

(a)

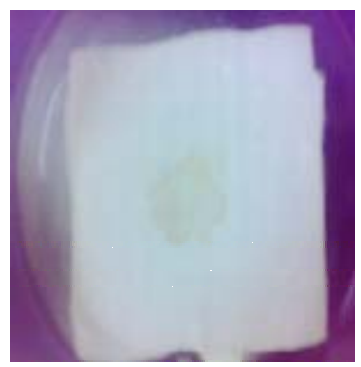

(c)

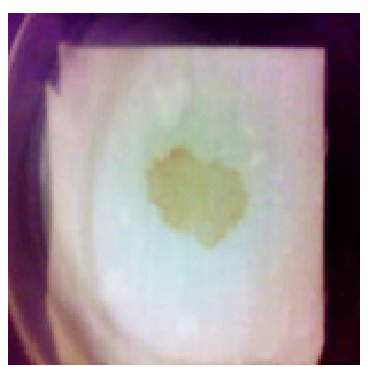

(b)

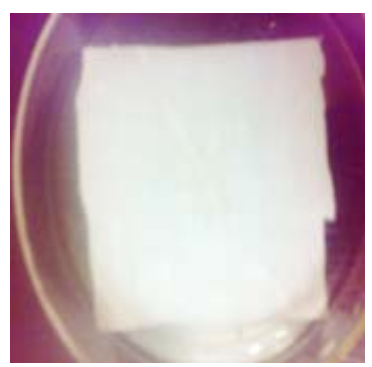

(d)
Figure 2. Removal of blood stains by protease enzyme. (a) Control; (b) Detergent only; (c) Enzyme only; (d) Enzyme + Detergent. power. Similar result was observed after the addition of protease from $B$. subtilis PE-11 [27] and B. brevis SSAI [30] and B. cereus [8] to commercial detergents.

In this respect, in 1994 enzymes used in detergent industry was accounted for about 112 million $\$$ of the world markets [29]. Alkaline proteases, particularly those which exhibit optimum activity at high $\mathrm{pHs}$ and high temperatures and used in detergent industry are preferred as an eco-friendly phosphate -free detergents [12].

The findings in this study suggest that the ability of the present alkaline protease of $B$. circulans 1 to hydrolyze sheep wool offering its possible application in removing hair from skin and hides in leather tanning industry, especially under alkaline conditions prevailing in such industry and instead of common chemicals which cause hazard environmental pollution. Furthermore, the present alkaline protease can be exploited in green recycling of feather wastes in poultry which offers cheap, safe and friendly environmental approaches that may help in reduction of pollution problems. The efficiency of $B$. circulans L. alkaline protease in removing blood stains encourages its possible use as suitable candidate for improving the cleaning property of Tide detergent.

\section{REFERENCES}

[1] Salleh, A.B., Rahman, R.N. and Basri, M. (2006) New lipases and proteases. Nova Science Publishers, New York.

[2] Syed, R., Rani, R., Masoodi, T.A., Shafi, G. and Alharbi, K. (2012) Functional analysis and structure determination of alkaline protease from Aspergillus flavus. Bioinformation, 8, 175-180. doi:10.6026/97320630008175

[3] Narsi-Reddy, M., Kumar, C.G., Swathi, K., Nagamani, B., Venkateshwar, S. and Rao, L.V. (2011) Extracellular alkaline protease production from isolated Bacillus subtilis SVR-07 by using submerged fermentation. International Journal of Pharmaceutical Research Development, 3, 216223.

[4] Uyar, F., Porsuk, I., Kizil, G. and Yilmaz, E.I. (2011) Optimal conditions for production of extracellular protease from newly isolated Bacillus cereus strain CA15. EuroAsian Journal of BioSciences, 5, 1-9. doi:10.5053/ejobios.2011.5.0.1

[5] Singh, R., Kumar, S. And Banik, R.M. (2013) Process optimization for hyperproduction of alkaline protease. Scholar's Press, AV Akademikerverlag GmbH \& Co. KG.

[6] Gerze, A., Omay, D. and Guvenilir, Y. (2005) Partial purification and characterization of protease enzyme from Bacillus subtilis. Applied Biochemistry and Biotechnology, 45, 121-124.

[7] Kebabci, O. and Cihangir, N. (2011) Partial purification of protease by a novel bacterium, Bacillus cereus and enzymatic properties. Journal of biological and biochemistry, 39, 39-43.

[8] Abou-Elela, G.M., Ibrahim, H.A.H, Hassan, S.W., AbdElnaby, H. and El-Toukhy, N.M.K. (2011) Alkaline pro- 
tease production by alkaliphilic marine bacteria isolated from Marsa-Matrouh (Egypt) with special emphasis on Bacillus cereus purified protease. African Journal of Biotechnology, 10, 4631-4642.

[9] Dodia, M.S., Joshi, R.H., Patel, R.K. and Singh, S.P. (2006) Characterization and stability of extracellular alkaline proteases from halophilic and alkaliphilic bacteria isolated from saline habitat of costal Gujarat, India. Brazilian Journal of Microbiology, 37, 276-282. doi:10.1590/S1517-83822006000300015

[10] Dodia, M.S., Bhimani, H.G., Rawal, C.M., Joshi, R.H. and Singh, S.P. (2008) Salt dependent resistance against chemical denaturation of alkaline protease from a newly isolated halophilic Bacillus sp. Bioresource Technology, 99, 6233-6227. doi:10.1016/j.biortech.2007.12.020

[11] Bernal, C., Cairo, J. and Coello, N. (2006) Purification and characterization of a novel exocellular keratinase from Kocuriarosea. Enzyme Microbiology and Technology, 38, 49-54. doi:10.1016/j.enzmictec.2005.02.021

[12] Mei, C. and Jiang, X. (2005) A novel surfactants and oxidation-stable alkaline protease from Vibrio metschnikovii DL 33.51. Process of Biochemistry, 40, 2167-2172. doi:10.1016/j.procbio.2004.08.007

[13] Saeki, K., Ozaki, K., Kobayashi, T. and Ito, S. (2007) Detergent alkaline proteases: Enzymatic properties, genes, and crystal structures. Journal of Bioscience and Bioengineering, 103, 501-508. doi:10.1263/jbb.103.501

[14] Sharaf, E.F. and Al-Fadel, K.A. (2012) Growth conditions influencing extracellular alkaline protease from haloalkaliphilic Bacillus circulans L. isolated from saline soil. Journal of International and Environmental Application and Science, 7, 613-621.

[15] Dixon, M. and Webb, E.C. (1961) Enzyme fractionation by salting out: A theoretical note. Advances in Protein Chemistry, 16, 197-219. doi:10.1016/S0065-3233(08)60030-3

[16] Joo, H.S., Kumar, C.G., Park, G.C., Kim, K.T., Paik, S.R. and Chang, C.S. (2002) Optimization of the production of an extracellular alkaline protease from Bacillus horikoshii. Process Biochemistry, 38, 155-159. doi:10.1016/S0032-9592(02)00061-4

[17] Lowry, O.H., Roserbrough, N.J., Farr, A.L. and Randall R. (1951) Protein measurement with folin phenol reagent. Journal of Biology and Biochemistry, 193, 265-275.

[18] Roa, S. (2004) Protein Purification Techniques. Oxford University Press, Oxford, 28-46.

[19] Sudha, J., Ramakrishnan, V., Madhusudhanan, N., Mandal, A.B. and Gurunathan, T. (2010) Studies on industrially significant haloalkaline protease from Bacillus sp. JSGT isolated from decaying of skin of Tannery. Journal of Advanced Laboratory Research and Biology, 16, 60-
67.

[20] Tekin, N., Cihan, A., Takac, Z. and Tuzun, C. (2012) Alkaline protease production of Bacillus cohnii APT5. Turkish Journal of Biology, 36, 430-444.

[21] Wang, S., Lin, X., Huang, X., Zheng, L. and Zilda, D.S. (2012) Screening and characterization of the alkaline protease isolated from PLI-1, a strain of Brevibacillus sp. collected from Indonesia's hot springs. Journal of Ocean University of China, 11, 213-218. doi:10.1007/s11802-012-1845-6

[22] Kumar, D.J., Venkatachalam, P., Govindarajan, N., Balakumaran, M.D. and Kalaichelvan, P.T. (2012) Production and purification of alkaline protease from Bacillus sp. MPTK 712 Isolated from Dairy Sludge. Global Veterinaria, 8, 433-439.

[23] Femi-Ola, T.O. and Oladokun, D.O. (2012) Partial purification and characterization of a thermostable alkaline protease from Lactobacillus brevis. Malaysian Journal of Microbiology, 8, 1-5.

[24] Schallmey, M., Singh, A. and Ward, O.P. (2004) Developments in the USA of Bacillus species for industrial production. Canadian Journal of Microbiology, 50, 1-17. doi:10.1139/w03-076

[25] Vidyasagar, M., Prakash, S., Litchfield, C. and Sreeramulu, K. (2006) Purification and characteri zation of a thermostable, haloalkaliphilic extracellular serine protease from the extreme halophilic archaeon Halogeometricum borinquense strain TSS101. Archaea, 2, 51-57. doi:10.1155/2006/430763

[26] Patel, R., Dodia, M. and Singh, S.P. (2005) Extracellular alkaline protease from a newly isolated haloalkaliphilic Bacillus sp.: Production and optimization. Proceeding of Biochemistry, 40, 3569-3575. doi:10.1016/j.procbio.2005.03.049

[27] Adinarayana, K., Ellaiah, P. and Prasad, D.S. (2003) Purification and partial characterization of thermostable serine alkaline protease from a newly isolated Bacillus subtilis PE-11, AAPS. Pharmaceutical Science and Technology, 4, 1-9.

[28] Donaghy, J.A. and Mckay, A.M. (1993) Production and properties of alkaline proteases by Aureobasidium pullulans. Journal of Applied Bacteriology, 74, 662-666. doi:10.1111/j.1365-2672.1993.tb05200.x

[29] Hodgson, J. (1994) The changing bulk of biocatalyst market. Journal of Biotechnology, 12, 289-290.

[30] Aftab, S., Ahmed, S., Saeed, S. and Rasool, S.A. (2006) Screening, isolation and characterization of alkaline protease producing by bacteria from soil. Pakistan Journal of Biological Science, 8, 212-217. 